\title{
Seagrass die-off in Florida Bay (USA): changes in shoot demographic characteristics and population dynamics in Thalassia testudinum
}

\author{
Michael J. Durako \\ Florida Marine Research Institute, 100 Eighth Ave. S.E., St. Petersburg, Florida 33701, USA
}

\begin{abstract}
Population dynamics, including demographic characteristics, of short-shoots of Thalassia testudinum were evaluated within 3 Florida Bay (USA) basins experiencing differing severities of seagrass die-off. Annual mean plastochrone intervals (PI) ranged from 14.1 to $20.6 \mathrm{~d}$, and they increased from the basin experiencing the most prolonged and extensive die-off to the basin least affected by dieoff. PIs calculated by leaf punching were always shorter than those estimated by cohort analyses. In all 3 basins, overall population age structure changed significantly between April 1989 and April 1990 population half-life, mean shoot age, the age of the oldest shoot, and shoot density declined, whereas rhizome apical density increased. An examination of the population dynamics of the $3 T$. testudinum populations revealed that both recruitment and mortality of short-shoots increased between April 1989 and April 1990, but the increase in mortality was proportionately greater. These changes indicated that the $T$. testudinum populations in Florida Bay were continuing to decline and that the declines corresponded to the increased extent and severity of short-shoot die-off.
\end{abstract}

KEY WORDS: Seagrass - Demography Die-off - Thalassia testudinum

\section{INTRODUCTION}

Rapid and widespread mortality of turtlegrass Thalassia testudinum Banks ex König has been recurring within Florida Bay (USA) since summer 1987. Although the causes of this mass mortality are not well understood, it has been hypothesized that a number of stress-inducing factors may have predisposed Florida Bay T. testudinum to this phenomenon (Robblee et al. 1991, Durako et al. 1994). Such factors include unusually high salinities and temperatures, hypoxia caused by elevated sulfide levels, reduced freshwater input from the Everglades watershed, seagrass community overdevelopment resulting from the reduced frequency of perturbation by tropical storms, and the proliferation of an endophytic marine slime mold, Labyrinthula sp. Die-off of $T$. testudinum, which is the dominant seagrass in Florida Bay (Zieman et al. 1989), has resulted in elevated inorganic and organic nutrient levels in the normally oligotrophic waters of Florida Bay and in increased turbidity in areas of exposed, eas- ily resuspended sediments (Durako et al. 1994). Eutrophication and increased turbidity have caused a general deterioration of the Florida Bay ecosystem, as evidenced by persistent and widespread algal blooms and sponge die-offs (J. H. Hunt pers. comm.).

Seagrass die-off has also been linked to significant changes in a number of structural and dynamic characteristics of Thalassia testudinum populations in Florida Bay (Durako in press). Reductions in shortshoot size and age (i.e. leaf length and width, numbers of leaf scars shoot ${ }^{-1}$ ) suggested that shoot demography had shifted to a younger age structure. Here, I use reconstructive aging techniques to examine the shoot age structure and population dynamics of 3 Florida Bay $T$. testudinum populations representing a range in the severity and extent of die-off. I then compare changes in demographic characteristics between 2 consecutive years to assess relative population status.

By examining the age structure of seagrass populations their status can be evaluated and their development can be predicted using estimates of recruitment 
and mortality. A major strength of this approach for assessing population condition is that the requisite data can be obtained from a single or a few sampling events (Duarte et al. 1994). Although techniques for aging seagrass shoots have been available for over 20 yr (Patriquin 1973, Durako \& Moffler 1987, Cox \& Tomlinson 1988), these techniques have only been used to examine population dynamics in a limited number of seagrasses [e.g. Cymodocea nodosa, Duarte \& Sand-Jensen (1990); Posidonia oceanica, Pergent \& Pergent-Martini (1990); Thalassia testudinum, Gallegos et al. (1993)]. Gallegos et al. $(1992,1993)$ demonstrated the great potential of reconstructive aging techniques and demographic analyses for examining the age-dependence and interannual variability of reproductive effort in $T$. testudinum and for comparing population dynamics of this species in the Mexican Caribbean. Reconstructive aging techniques can also be used to identify whether a population is expanding, declining, or in steady state (Duarte \& Sand-Jensen 1990, Duarte et al. 1994). Because of the simple architecture of seagrasses - all are rhizomatous plants that yrow by reiteration oí a iimited set of modules (Duarte 1991) - the use of reconstructive aging techniques should be applicable to the study of most seagrass flora. Essentially the same reconstructive aging techniques have been used to study the growth and demography of a range of plants (Sarukhán 1978, Duke \& Pinzón 1992).

\section{MATERIALS AND METHODS}

Samples of Thalassia testudinum to be used in demographic analyses were obtained every 2 mo from April 1989 to June 1990 as part of a quantitative sampling program monitoring variations in structure and $d y-$ namics relative to the die-off phenomenon (Durako in press). Only the April 1989 and April 1990 sample data will be compared here. Sampling was conducted in Rankin Lake (RNK), Johnson Key (JKB), and Rabbit Key (RKB) basins (Fig. 1). These 3 basins represent gradients in severity and extent of the seagrass die-off and in physical characteristics. Rankin Lake has had the most prolonged seagrass die-off and, during this study, had numerous, relatively large die-off patches. Seagrass die-off in Florida Bay was first observed in the Rankin Lake area during summer 1987 (Robblee et al. 1991). Circulation in this interior basin is restricted and the water is seasonally hypersaline (Schomer \&

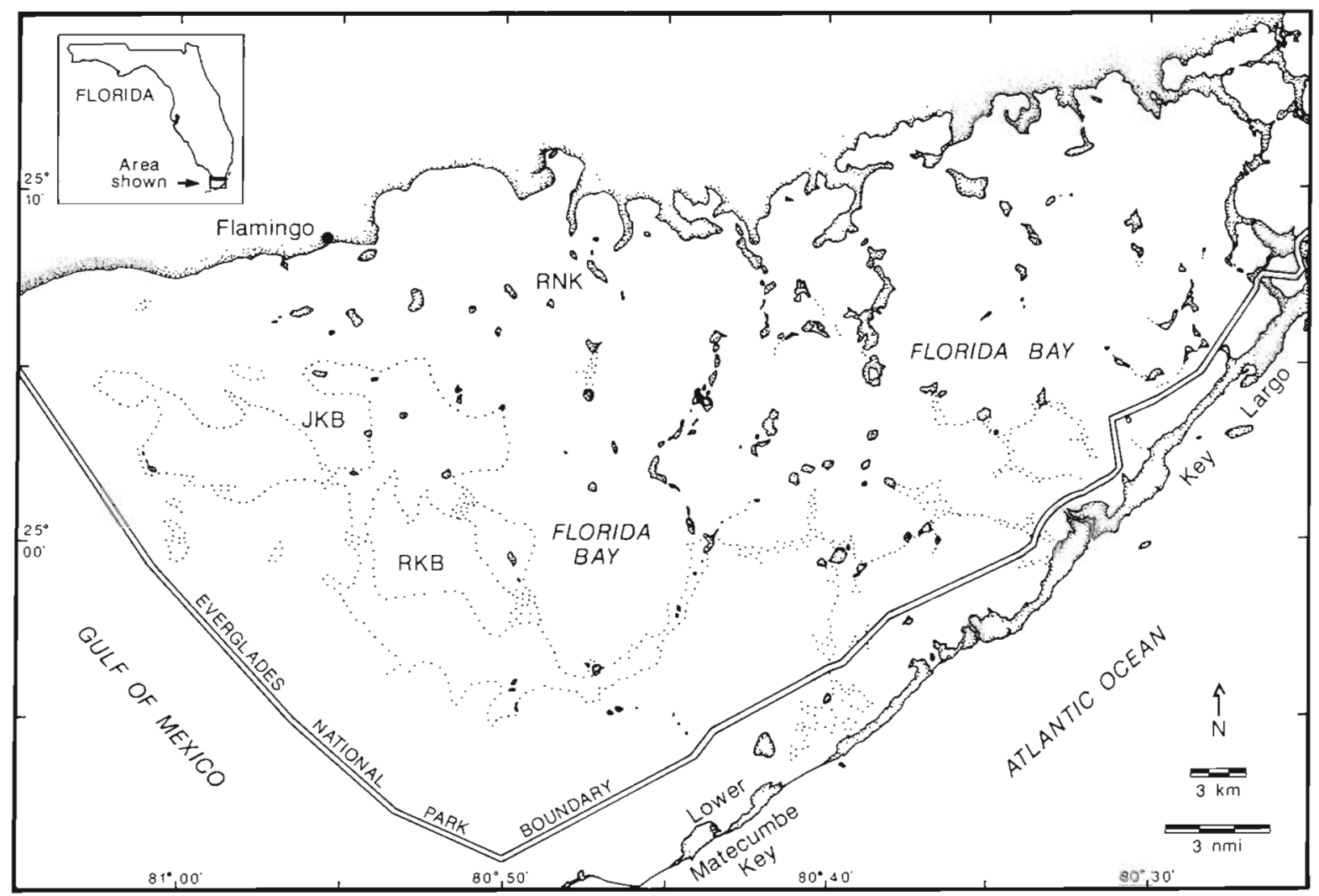

Fig. 1. Location of sample sites in Florida Bay, USA. RNK: Rankin Lake basin; JKB: Johnson Key basin; RKB: Rabbit Key basin 
Drew 1982). Johnson Key basin has less variation in salinity than Rankin Lake because of greater tidal flushing and better circulation (Schomer \& Drew 1982); Johnson Key basin had mostly small ( $<10 \mathrm{~m}$ diameter) die-off patches, predominantly along the basin margins. Rabbit Key basin is located along the more oceanic southwestern margin of Florida Bay and has near-normal marine salinities (Schomer \& Drew 1982). Rabbit Key basin also had the most restricted distribution of die-off during the study period (northern and eastern margins).

Each basin was subdivided by a $0.5 \mathrm{n}$ mile sampling grid with each grid intersection point being assigned a station number. Samples of Thalassia testudinum were obtained along transects at the first 3 randomly chosen stations per basin with visible die-off patches. Along each transect, $0.04 \mathrm{~m}^{2}$ quadrats were placed next to the transect line at 5 uniformly spaced stations representing a gradient from die-off $(2 \mathrm{~m}$ from the die-off/ healthy ecotone) to healthy ( $2 \mathrm{~m}$ inside bed) zones. Plastochrone intervals ( $\mathrm{PI}, \mathrm{d}_{\text {leaf }}{ }^{-1}$ shoot $^{-1}$ ) were determined by leaf punching all short-shoots within the quadrats with a 21 gauge needle (Brouns 1985). After periods of 9 to $15 \mathrm{~d}$, all plants within the quadrats were harvested. At this time, the numbers of live shortshoots and live rhizome apices were counted. Plant material was separated into 2 fractions - short-shoots, and roots and rhizomes. Each fraction was washed free of sediments, placed in separate whirl-pak bags, and frozen for subsequent analysis.

For each short-shoot, the number of old (punched) and new (unpunched) green leaf blades was counted. Leaf and sheath material was then peeled away from each short-shoot, and the number of leaf scars was recorded (Fig. 2). PI was calculated by 2 methods: (1) by multiplying the number of leaf-punched shoots by the time interval between marking and harvest, then dividing by the number of new leaves produced (Patriquin 1973, Brouns 1985); and (2) from the differences in numbers of leaf scars between successive annual cohorts (large numbers of short-shoots of similar age) divided by $365 \mathrm{~d}$. Cohorts appear as distinct modes in frequency distributions of shoot age (Duarte \& Sand-Jensen 1990). Shoot age was estimated as the product of the total number of leaf scars plus the number of standing leaves on a shoot and the mean PI that was calculated for each basin.

April 1989 and April 1990 samples were used in the demographic analyses to assess year-to-year changes in population age structure. Shoot demography was characterized by 6 descriptors (Duarte \& Sand-Jensen 1990): (1) mean shoot age; (2) coefficient of variation of shoot age, which measures the extent of demographic heterogeneity of the population; (3) age of the oldest shoot; (4) instantaneous mortality rate $(M$, In

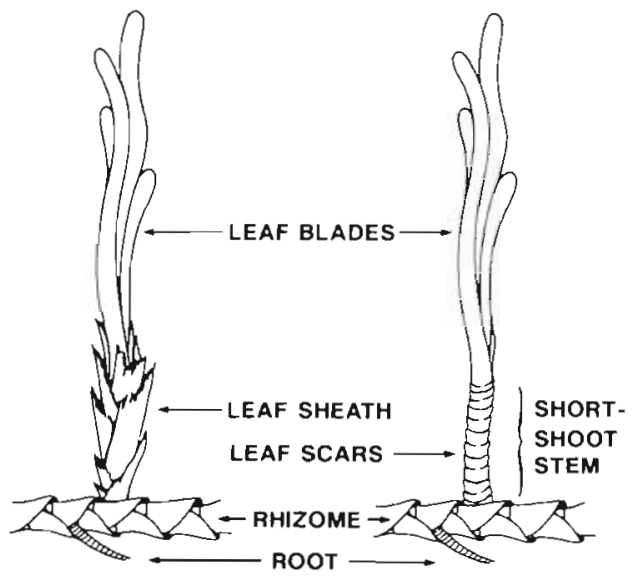

Fig. 2. Thalassia testudinum. Shoot morphology showing different modules and method to remove leaf sheath and count leaf scars

units $\mathrm{yr}^{-1}$ ) derived from the number of shoots in consecutive cohorts and estimated by fitting the equation $N(t)=N(0) e^{-M t}$ to observed data, where $N(t)$ is the number of shoots at time $t, N(0)$ represents the number of shoots at $t=0_{i}(5)$ population half-life in years as $\mathrm{T}_{1 / 2}=\ln 2 / M$, which provides a more intuitive description of the influence of shoot mortality on population turnover; and (6) gross shoot recruitment ( $R_{\text {gross }}$ In units $\mathrm{yr}^{-1}$ ) in the year preceding sampling, derived from the proportion of shoots $<1$ yr and calculated as $R_{\text {gross }}=\ln \mathrm{N}_{t}-\ln \mathrm{N}_{t+1}$, where $\mathrm{N}_{t}$ is the total number of shoots and $N_{t+1}$ is the number of shoots older than a year. Gross short-shoot recruitment and mortality rates were used to calculate population growth as net annual new shoot production $\left(P_{\text {net }}=R_{\text {gross }}+M\right)$, which predicts whether the population is expanding $\left(R_{\text {gross }}>\right.$ $M)$, declining $\left(R_{\text {gross }}<M\right)$, or in steady state $\left(R_{\text {gross }}=\right.$ M) (Duarte et al. 1994).

Significance of changes in shoot age distribution between April 1989 and April 1990 samples was determined using the Kolmogorov-Smirnov test, which compared the cumulative age distributions between the 2 years (Sokal \& Rohlf 1981). Shoot age and density, rhizome apical density, and PI data were evaluated for normality and homogeneity of variance and were transformed, if necessary, to satisfy the assumptions of parametric statistics. One-way ANOVAs were used to assess the significance of the variation in PI among basins and between methods. Two-way ANOVAs were used to assess the significance and magnitude of the variation in shoot age, shoot density, and rhizome apical density attributable to differences among basins (RNK, JKB, and RKB) and between years (April 1989 vs April 1990); Type III rather than Type I sum of squares was used in the 2-way ANOVAs for calculating $F$-values. This allowed evaluation of each 
main effect without involving parameters of the other main effect or the interaction term. Where significant, main effects were identified and means were compared using Duncan's Multiple Range test. All ANOVA and Duncan's calculations were performed using Statistical Analysis System (SAS) programs (SAS Institute, Inc. 1985); mortality estimates were obtained by nonlinear regression (SigmaPlot, Jandel Scientific Corporation, San Rafael, CA, USA).

\section{RESULTS AND DISCUSSION}

Measured and estimated plastochrone intervals (PIs) for Florida Bay Thalassia testudinum populations (Table 1) fell within the range of values reported for this species (10 to $26 \mathrm{~d}$; Patriquin 1973, Zieman 1982, Gallegos et al. 1992). PIs calculated by leaf punching exhibited significant site-based differences $\left(F_{\text {ste }}=\right.$ 4.01 , df $=2,359, \mathrm{p}<0.02$ ); PIs decreased from the population least affected by die-off to the population experiencing the most severe die-off (i.e. $\mathrm{PI}_{\mathrm{RKB}}>\mathrm{PI}_{\mathrm{JKB}}>$ $\mathrm{PI}_{\text {RNK }}$ ). Miean Pí for the Rankin Lake (RNKK) population was significantly shorter than that for the other 2 populations, which were not significantly different from each other. In a study on die-off related changes in structural and dynamic characteristics of $T$. testudinum, Durako (in press) observed that PIs were shortest (as short as $4 \mathrm{~d} \mathrm{leaf}^{-1}$ shoot $^{-1}$ ) for short-shoots surviving within die-off patches; therefore, the lower mean PI for the RNK population may reflect the greater extent of die-off in this basin.

Table 1. Thalassia testudinum. Calculated (leaf punch) and estimated (cohort) plastochrone intervals (PI) for turtlegrass from 3 basins in Florida Bay, USA. Means ( \pm SE)

\begin{tabular}{|c|c|c|c|}
\hline Parameter & $\begin{array}{c}\text { Rankin } \\
\text { Lake }\end{array}$ & $\begin{array}{c}\text { Johnson } \\
\text { Key }\end{array}$ & $\begin{array}{c}\text { Rabbit } \\
\text { Key }\end{array}$ \\
\hline \multicolumn{4}{|l|}{ Calculated } \\
\hline PI (d leaf ${ }^{-1}$ shoot $^{-1}$ ) & $\begin{array}{l}12.9 \\
(1.7)\end{array}$ & $\begin{array}{l}17.8 \\
(1.5)\end{array}$ & $\begin{array}{r}18.2 \\
(1.7)\end{array}$ \\
\hline \multicolumn{4}{|l|}{ Estimated } \\
\hline \multicolumn{4}{|c|}{ Leaves produced shoot ${ }^{-1} \mathrm{yr}^{-1}$} \\
\hline Apr 1989 & $\begin{array}{l}25.6 \\
(2.5)\end{array}$ & $\begin{array}{l}20.9 \\
(1.1)\end{array}$ & $\begin{array}{l}18.8 \\
(1.6)\end{array}$ \\
\hline Apr 1990 & $\begin{array}{l}21.5 \\
(2.6)\end{array}$ & $\begin{array}{l}20.7 \\
(1.8)\end{array}$ & $\begin{array}{l}18.9 \\
(1.7)\end{array}$ \\
\hline \multicolumn{4}{|l|}{ PI (d leaf ${ }^{-1}$ shoot $\left.^{-1}\right)$} \\
\hline Apr 1989 & $\begin{array}{l}14.9 \\
(1.6)\end{array}$ & $\begin{array}{l}18.0 \\
(1.0)\end{array}$ & $\begin{array}{l}20.6 \\
(1.6)\end{array}$ \\
\hline Apr 1990 & $\begin{array}{l}17.9 \\
(2.8)\end{array}$ & $\begin{array}{l}18.3 \\
(1.6)\end{array}$ & $\begin{array}{l}20.4 \\
(2.0)\end{array}$ \\
\hline
\end{tabular}


Fig. 3. Thalassia testudinum. Age-frequency distribution (bars) and fitted mortality (dashed line with parameter estimates $\pm \mathrm{SE}$ ) of short-shoots collected from Rankin Lake basin during April 1989 and April 1990

Estimation of the PIs by counting the leaf-scar differences among cohorts revealed that the Thalassia testudinum populations in Florida Bay generally produce 2 cohorts $\mathrm{yr}^{-1}$ - one during late spring and the other during the fall (see Figs. 3 to 5). Because shoot recruitment is closely linked to rhizome growth in $T$. testudinum (Gallegos et al. 1993), this also suggests that rhizome growth is higher during spring and fall and may be reduced during summer and winter (Duarte et al. 1994). PIs estimated by cohort analyses exhibited the same trend as those calculated by leaf punching (i.e. $\mathrm{PI}_{\mathrm{RKB}}>\mathrm{PI}_{\mathrm{JKB}}>\mathrm{PI}_{\mathrm{RNK}}$ ). Cohort-estimated PIs were 0.2 to $5 \mathrm{~d}$ longer than those measured by leaf punching (Table 1). Because cohort-based PIs are derived from the number of leaves produced per shoot per year over the life span of short-shoots (up to $8 \mathrm{yr}$ ), the longer estimated PIs may reflect the influence of different environmental conditions or population status in the recent past.

The age structures of living short-shoots during April 1989 and April 1990 showed a general increase in the abundance of shoots up to ages of about $0.5 \mathrm{yr}$ to slightly less than 1 yr (Figs. 3 to 5). The relatively low abundance of very young shoots indicates that most shoot recruitment, for the spring cohort, occurred 

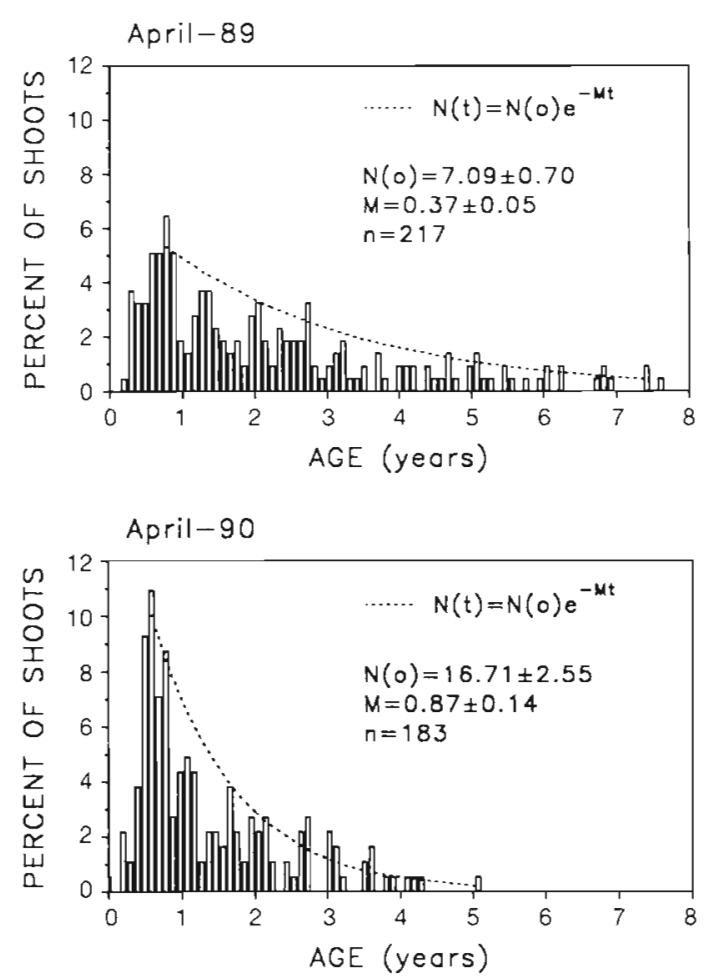

Fig. 4. Thalassia testudinum. Age-frequency distribution (bars) and fitted mortality (dashed line with parameter estimates \pm SE) of short-shoots collected from Johnson Key basin during April 1989 and April 1990

before the April sampling (Gallegos et al. 1993, Duarte et al. 1994) and reflects that the first 6 or 7 leaves are produced in a relatively short time period ( 3 to $4 \mathrm{~d}_{\text {; }}$ Patriquin 1973). Peaks in abundance were followed by an exponential decline in the number of older shoots, reflecting shoot mortality.

Within-basin comparisons of the population age structures between 1989 and 1990 indicated that significant demographic differences $\left(D_{\text {calc }}>D_{0.05}\right)$ occurred between the 2 years at all 3 sites. Changes in the demographic characteristics of Thalassia tes tudinum short-shoots between 1989 and 1990 suggest that all 3 populations were in an accelerating state of decline (Table 2). Mortality rates for the RNK popula-
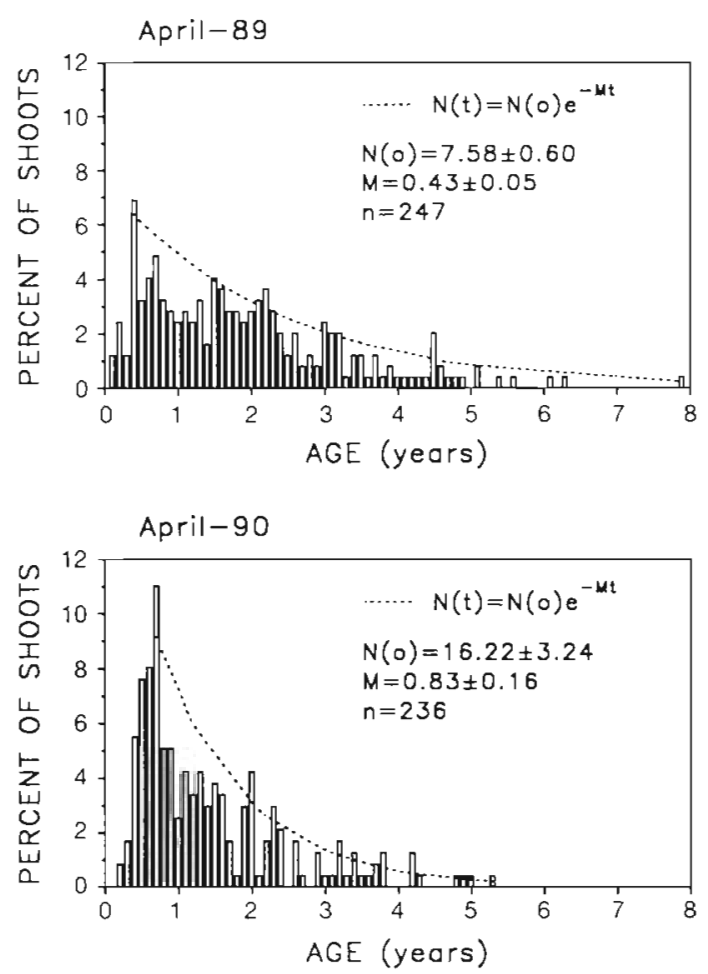

Fig, 5. Thalassia testudinum. Age-frequency distribution (bars) and fitted mortality (dashed line with parameter estimates $\pm \mathrm{SE}$ ) of short-shoots collected from Rabbit Key basin during April 1989 and April 1990

tion were 2 to 3 times higher than those of the JKB and RKB populations for both years. Mortality rates increased between 1989 and 1990 in all basins, and although population half-lives were shorter at RNK, they exhibited the greatest decline in JKB and RKB, where population half-lives were reduced by $50 \%$. This indicates that even though the RNK population was in the worst condition, JKB and RKB populations were deteriorating more rapidly. In April 1989, recruitment balanced mortality in the JKB and RKB populations ( $P_{\text {net }}$ close to 0$)$, indicating population stability. In contrast, recruitment rates for the RNK population, which at the time of sampling had been subjected to widespread die-off for 2 yr, were well below mortality

Table 2. Thalassia testudinum. Indices of turtlegrass population dynamics from 3 Flonida Bay basins

\begin{tabular}{|lcccccr|}
\hline \multirow{2}{*}{ Parameter } & \multicolumn{2}{c}{ Rankin Lake } & \multicolumn{2}{c|}{ Johnson Key } & \multicolumn{2}{c|}{ Rabbit Key } \\
& Apr 1989 & Apr 1990 & Apr 1989 & Apr 1990 & Apr 1989 Apr 1990 \\
\hline Gross recruitment (ln units $\mathrm{yr}^{-1}$ ) & 0.84 & 1.51 & 0.42 & 0.71 & 0.39 \\
Mortality (ln units yr ${ }^{-1}$ ) & 1.35 & 2.18 & 0.37 & 0.87 & 0.55 \\
Population half-life (yr) & 0.51 & 0.31 & 1.87 & 0.79 & 0.43 & 0.83 \\
Net shoot production (ln units $\mathrm{yr}^{-1}$ ) & -0.51 & -0.67 & 0.05 & -0.16 & -0.04 & -0.28 \\
\hline
\end{tabular}


rates in 1989, indicating that this population was already in a state of severe decline at this time (Table 2). T. testudinum populations responded to the increasing mortality rates between 1989 and 1990 by increasing recruitment rates. Despite this, recruitment rates became substantially smaller relative to mortality rates in all 3 populations, suggesting that the populations would continue to decline. Shoot densities in 1991 are predicted to be 15 to $49 \%$ lower than those in 1990 with the greatest declines occurring in the JKB and RKB populations.

The changes in mortality and recruitment patterns from April 1989 to April 1990 resulted in shifts in several other shoot demographic characteristics. Mean shoot age significantly declined between 1989 and

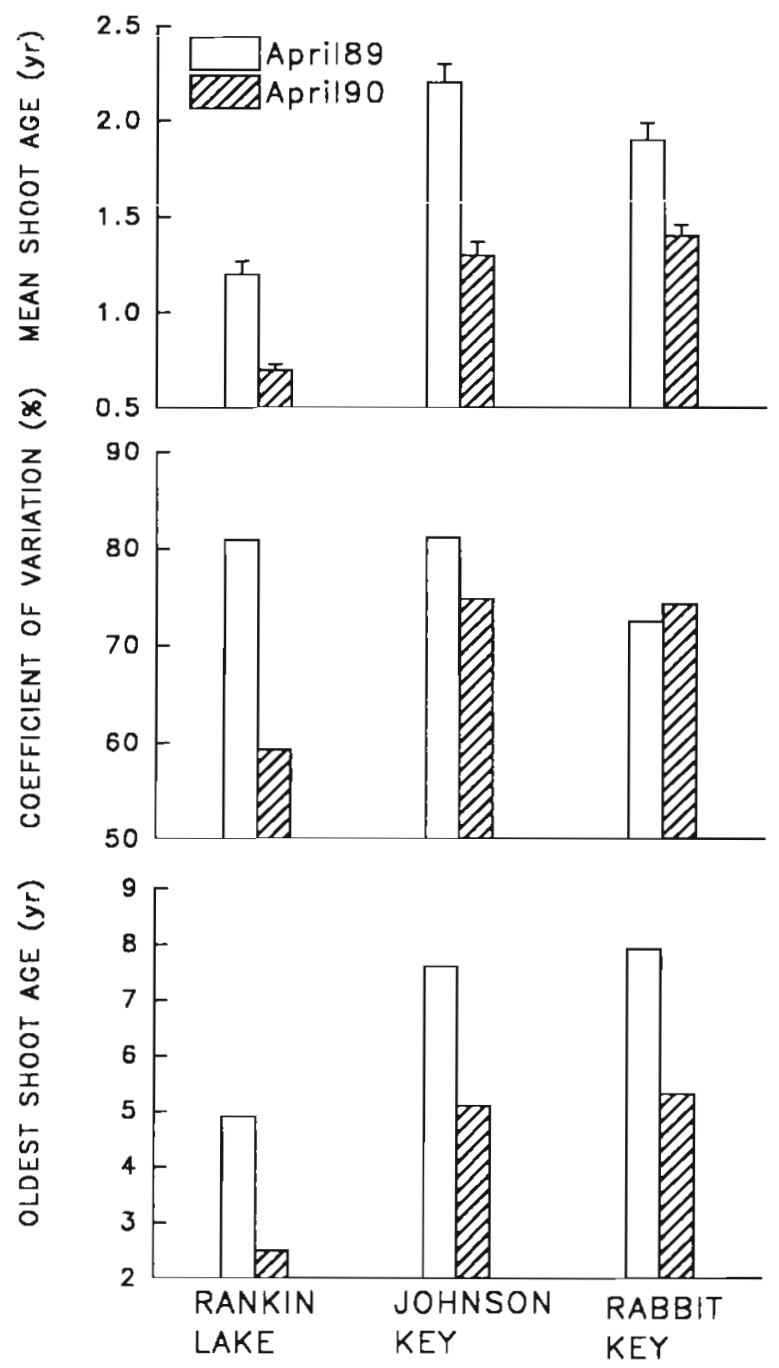

Fig. 6. Thalassia testudinum. Mean short-shoot age (+ SE), coefficient of variation of the mean short-shoot age, and the age of the oldest living short-shoots collected during April 1989 and April 1990 from 3 basins in Florida Bay
1990 at all 3 sites $\left(F_{1.358}=30.4, F_{1,399}=30.7\right.$, and $F_{1.482}=$ 17.6 for $\mathrm{RNK}, \mathrm{JKB}$, and $\mathrm{RKB}$, respectively); RNK had the lowest mean shoot age in both years (Fig. 6). The decline in mean shoot age reflects changes in 2 processes between 1989 and 1990: (1) increased recruitment of new shoots (Table 2); and (2) a reduction in shoot life spans (possibly by increased or preferential mortality of older shoots; Table 2, Figs. 3 to 5). The increase in recruitment reflected recolonization of dieoff patches by prolific branching and production of new rhizomes by survivor short-shoots (Durako in press). Rhizome apical densities significantly increased between April 1989 and April $1990\left(F_{1,29}=5.56,5.15\right.$, and 15.77 for RNK, JKB, and RKB, respectively), despite a nonsignificant decreasing trend in shortshoot densities (Fig. 7). The reduction in shoot life spans between 1989 and 1990 resulted in a truncation of the oldest portion of the age-frequency distribution (Figs. 3 to 5) and in a dramatic reduction in the maximum life spans of shoots (i.e. age of the oldest shoot;
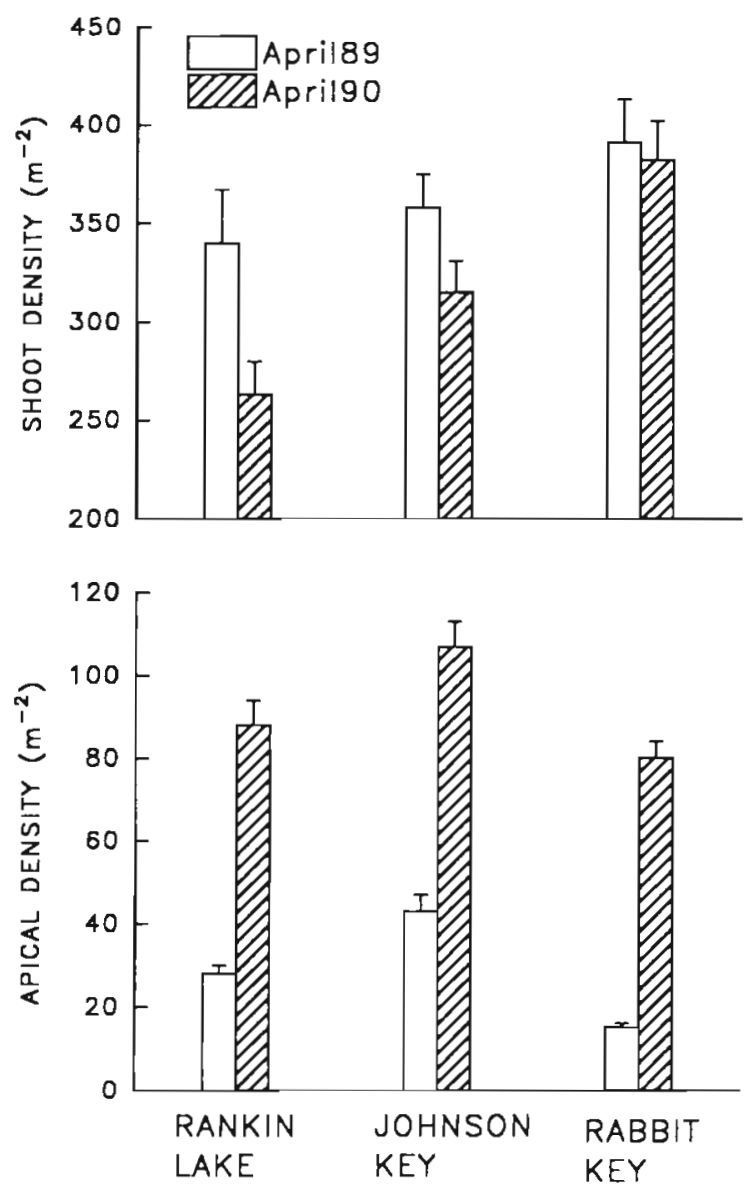

Fig. 7. Thalassia testudinum. Short-shoot and rhizome apical densities (means + SE) during April 1989 and April 1990 in 3 basins in Florida Bay 
Fig. 6) in the 1990 samples. Ages of the oldest shoots in 1989 were similar to those of the oldest shoots reported from Barbados (8 to 10.5 yr; Patriquin 1973). Mississippi, USA ( 7 yr; Eleuterius 1987), and Mexico (6 to $9 \mathrm{yr}$; Gallegos et al. 1992, 1993). However, the age of the oldest shoot age declined by more than 2 yr in the 1 yr period from 1989 to 1990, reflecting increased mortality of older shoots. These patterns suggest that the Thalassia testudinum populations within Florida Bay have a relatively high potential to recover if the factors causing the short-shoot mortality disappear. The changes in population age structure between 1989 and 1990 resulted in over a $20 \%$ reduction in the demographic heterogeneity of the RNK population but only a slight reduction in the JKB population as measured by the coefficient of variation of the mean shoot age (Fig. 6); the RKB population, which has experienced the least die-off, also exhibited the least change in demographic heterogeneity.

\section{Conclusions}

The ability to age shoots of Thalassia testudinum provides a powerful tool for elucidating population dynamics of this species. However, this demographic technique has only recently been used to evaluate the dynamics and status of $T$. testudinum populations (Gallegos et al. 1992, 1993, Duarte et al. 1994) and has yet to be applied to the congener species Halodule wrightii Aschers. and Syringodium filiforme Kütz. An examination of the population age structure of 3 populations of $T$. testudinum in Florida Bay over a 1 yr period revealed significant changes in shoot demographic characteristics and population dynamics. These changes indicated that the populations were in various states of decline that corresponded to the extent and severity of short-shoot die-off. Gallegos et al. (1993) observed differences in shoot recruitment and mortality of $T$. testudinum from the Mexican Caribbean which corresponded to a gradient of eutrophication, suggesting that this demographic approach may have wide application to the assessment of seagrass population status.

Predictions based on estimates of shoot recruitment and mortality suggest that net loss of short-shoots will continue and that even greater deterioration of Thalassia testudinum populations in Florida Bay may be expected in the near future. This is consistent with basin-level observations in Rankin Lake on frequency of occurrence and abundance which also indicate increasing declines of $T$. testudinum which have been partially offset by rapid recolonization of the pioneering species Halodule wrightii (Durako et al. 1994). Although mortality rates have increased in all 3 basins, the decline in shoot densities should be faster in JKB and RKB, where population half-lives showed the highest drop. The demographic analyses performed here revealed that the RNK population is already severely affected by die-off, and it predicts that declines in the other 2 populations are soon to follow. Yet, the fact that $T$. testudinum populations respond to increased mortality by increasing rhizome branching represents a potential mechanism for rapid recovery - if enough shoots survive the present period of catastrophic mortality.

Acknowledgements. I thank Dr Carlos M. Duarte and his students for their enlightening discussions on the topics of seagrass growth and population dynamics and for their comments on an earlier version of this manuscript. I also thank Glenn Harmon, Brenda Hedin, Rebecca Wharrie, Kathleen Kuss and Dr Michael Robblee for assistance in the field and laboratory. Support for this study was provided by the Florida Department of Environmental Regulation, Office of Coastal Management, using funds made available through the National Oceanic and Atmospheric Administration under the Coastal Zone Management Act of 1972, as amended, and by the U.S. Department of the Interior, Fish and Wildlife Service Federal Aid for Sportfish Restoration Project F-44. Additional logistical support was provided by the Everglades National Park Research Center. Travel support was provided by the Marine Spill Response Corporation, Washington, DC

\section{LITERATURE CITED}

Brouns, J. J. W. M. (1985). The plastochrone interval method for the study of the productivity of seagrasses; possibilities and limitations. Aquat. Bot. 21: 71-88

Cox, P. A., Tomlinson, P. B. (1988). Pollination ecology of a seagrass, Thalassia testudinum (Hydrocharitaceae), in St Croix. Am. J. Bot. 75: 958-965

Duarte, C. M. (1991). Allometric scaling of seagrass form and productivity. Mar. Ecol. Prog. Ser. 77: 289-300

Duarte, C. M., Marbá, N., Agawín, N., Cebrián, J., Enríquez. S., Fortes, M. D., Gallegos, M. E., Merino, M., Olesen, B. Sand-Jensen, K., Uri, J., Vermaat, J. (1994). Reconstruction of seagrass dynamics: age determinations and associated tools for the seagrass ecologist. Mar. Ecol. Prog. Ser. 107: $195-209$

Duarte, C. M., Sand-Jensen, K. (1990). Seagrass colonization: biomass development and shoot demography in Cymodocea nodosa patches. Mar. Ecol. Prog. Ser. 67: 97-103

Duke, N. C., Pinzón, M. (1992). Aging Rhizophora seedlings from leaf scar nodes: a technique for studying recruitment and growth in mangrove forests. Biotropica 24: 173-186

Durako, M. J. (in press). Indicators of seagrass ecological condition: an assessment based on spatial and temporal changes associated with the mass mortality of the tropical seagrass Thalassia testudinum. In: Dyer, K. R., D'Elia, C. F. (eds.) Changes in fluxes in estuaries: implications for science to management. Olsen \& Olsen, Fredensborg

Durako, M. J., Barber, T. R., Bugden, J B. C., Carlson, P. R., Fourqurean, J. W., Jones, R. D., Porter, D., Robblee, M. B., Yarbro, L. A., Zieman, R. T., Zieman, J. C. (1994). Seagrass die-off in Florida Bay. In: Douglas, J. (ed.) Proceedings of the Gulf of Mexico Symposium. U.S. EPA, Tarpon Springs, FL, p. 14-15 
Durako, M. J., Moffler, M. D. (1987). Factors affecting the reproductive ecology of Thalassia testudinum (Hydrocharitaceae). Aquat. Bot. 27: 79-95

Eleuterius, L. N. (1987). Seagrass ecology along the coasts of Alabama, Louisiana, and Mississippi. In: Durako, M. J., Phillips, R. C., Lewis, R. R. (eds.) Proceedings of the symposium on subtropical-tropical seagrasses of the southeastern United States. Fla mar. Res. Publ. 42: $11-20$

Gallegos, M. E., Merino, M., Marbá, N., Duarte, C. M. (1992). Flowering of Thalassia testudinum Banks ex König in the Mexican Caribbean: age-dependence and interannual variability. Aquat. Bot. 43: 249-255

Gallegos, M. E., Merino, M., Marbá, N., Duarte, C. M. (1993). Biomass and dynamics of Thalassia testudinum in the Mexican Caribbean: elucidating rhizome growth. Mar. Ecol. Prog. Ser. 95: 185-192

Patriquin, D. (1973). Estimation of growth rate, production and age of the marine angiosperm Thalassia testudinum König. Caribb. J. Sci. 13: 111-123

Pergent, G., Pergent-Martini, C. (1990). Some applications of lepidochronological analysis in the seagrass Posidonia oceanica. Botanica mar. 33: 299-310

This article was presented by G. W. Thayer (Senior Editorial Advisorl, Beaufort, N. Carolina, urs 4
Robblee, M. B., Barber, T R., Carlson, P. R, Durako, M. J., Fourqurean, J. W., Muehlstein, L. K., Porter, D., Yarbro, L. A., Zieman, R. T., Zieman, J. C. (1991). Mass mortality of the tropical seagrass Thalassia testudinum in Florida Bay (USA). Mar. Ecol. Prog. Ser. 71: 297-299

Sarukhán, J. (1978). Studies on the demography of tropical trees. In: Tomlinson, P. B., Zimmerman, H. (eds.) Tropical trees as living systems. Cambridge University Press, Cambridge, p. 163-184

SAS Institute, Inc. (1985). SAS user's guide: statistics version 5 edn. SAS Institute, Inc., Cary, NC

Schomer, N. S., Drew, R. D. (1982). An ecological characterization of the lower Everglades, Florida Bay and the Florida Keys. U.S. Fish Wildl. Serv., Office Biol. Serv., Washington, DC, FWS/OBS-82/58.1

Sokal, R. R., Rohlf, F. J. (1981). Biometry, 2nd edn. W. H. Freeman, New York

Zieman, J. C. (1982). The ecology of the seagrasses of south Florida: a community profile. U.S. Fish Wildl. Serv., Office Biol. Serv. Washington, DC, FWS/OBS $-82 / 25$

Zieman, J. C., Fourqurean, J. W., Iverson, R. L. (1989). Distribution and abundance of seagrasses in Florida Bay. Bull. mar. Sci. 44: 292-311

Manuscript first received: November 1, 1993

Revised version accoptcd: March 31,1004 